\title{
Kuntatason aikuiskoulutussuunnittelun käynnistäminen Mikkelin läänissä
}

\section{A. Projektin lähtökohdat}

Mikkelin läänissä on 29 kuntaa ja asukkaita noin 200 000. Ammatissa toimivaa väestöä oli vuonna 1985 yhteensä 93 000, josta noin $20 \%$ maa- ja metsätalouden ja samoin noin $20 \%$ teollisuuden palveluksessa. Maatalous on pientilavaltaista. Teollisuudessa suurin ryhmä on metalli- ja konepajatuotteiden valmistus, toiseksi suurin työllistäjä on puutavaran valmistus. Yhteiskunnalliset ja henkilökohtaiset palvelut ovat voimakkaasti kasvava ammattiryhmä.

Läänissä ei ole omaa korkeakoulua. Keskiasteen oppilaitoksia on 28 , joissa on riittävästi koulutuspaikkoja läänin tarvetta ajatellen. Ammatillista aikuiskoulutusta antavat ammatillisten oppilaitosten kurssitoiminta ja kaksi ammattikurssikeskusta. Kahdeksan kansanopistoa ja 17 kansalaisopistoa keskittyvät yleissivistävään aikuiskoulutukseen. Erilaisilla yhdistyksillä on lisäksi kurssi- ja neuvontatoimintaa. Jokaisessa kunnassa on kirjastolaitos. Koulutus- ja sivistyspalvelut jakautuvat varsin tasaisesti läänin neljän tasavahvan talousalueen kesken.

\section{B. Tavoitteet}

Lääninhallituksen kouluosasto aloitti projektin oikeastaan jo 1970-luvulla, jolloin ruvettiin kartoittamaan läänin aikuiskoulutuspalveluja ja pohtimaan alalla toimivien laitosten yhteistyötä ja työnjakoa. Kouluosastolla projektista rastaa työryhmä, johon kuuluu vapaan sivistystyön tarkastaja, ammattikasvatustarkastaja, suunnittelija ja tutkimussihteeri. Projektia vedetään muun virkatyön ohella.

Lääninhallitus on järjestänyt neljä aikuiskoulutuksen suunitteluseminaaria kuntien edustajille. Seminaareissa on pohdittu asiantuntijoiden alustusten pohjalta kuntien aikuiskoulutuspalvelujen kehittämistä. Lääninhallitus on sitten koonnut kertynyttä kokemusta ohjeistoksi, jota on lähetetty kuntiin.
Jokaisessa kunnassa on asetettu aikuiskoulutustoimikunta tai vastaava. Näitä asiantuntijaryhmiä on kahta päätyyppiä: 1) poliittisesti valittu kunnallinen toimikunta ja 2) paikallisten oppilaitosten edustajien muodostama neuvottelukunta. Edellisellä on ollut enemmän mahdollisuuksia saada aikuiskoulutusta mukaan kuntasuunnitelmiin, jälkimmäinen taas on keskittynyt oppilaitosten keskinäiseen informaation vaihtoon.

Lääninhallituksen päämääränä on ollut ylläpitää yhteyttä kuntien työryhmiin siten, että työ on pysynyt vireillä ja kuntien aikuiskoulutuspalvelut on saatu kartoitettua. Kuntien raporteissa on yleensä otettu huomioon myös ne esimerkiksi talousalueen keskuksessa olevat palvelut, joita oman kunnan asukkaat käyttävät. Eräissä kunnissa on tehty kyselyitä, joilla on kartoitettu koulutustarpeita.

Kun koulutustarpeet ja tarjotut koulutuspalvelut on saatu kartoitettua, on voitu ruveta suunnittelemaan palvelujen kehittämistä. Tavoitteena saada käytössä olevat resurssit mahdollisimman tehokkaaseen käyttöön.

Varsin monessa kunnan aikuiskoulutussuunnitelmassa todetaan tavoitteeksi kunnan luontaisten elinkeinojen tukeminen. Tämä sopii varsin hyvin yhteen lääninhallituksen johdon ajaman ekolääni-ajattelun kanssa. Nykyaikaisen teknologian ei kuitenkaan katsota olevan ristiriidassa tähän nähden. Tendenssinä on korostaa uudessa teknologiassa pehmeiden arvojen huomioon ottamista ja luontoa säästäviä vaihtoehtoja.

\section{Prosessi}

Kysymyksessä on siis itse asiassa aikuiskoulutuksen hallinnoimiseen ja järjestämiseen keskittyvä projekti. Mahdollisesti projektin edetessä tullaan syventymään joihin koulutussisältöihin tarkemmin. Eräs tällainen alue saattaisi olla luonnonmukainen viljely, siihen liittyvän tietouden levittäminen maataloudessa työskentelevien keskuuteen. 
Toistaiseksi lääninhallituksen työryhmä on paitsi laatinut yhteenvetoja ja ohjeistoa ja järjestänyt seminaareja, myös vieraillut kunnissa ja oppilaitoksissa. Voitaneen sanoa, että lääninhallituksen kannalta ainakin työmäärää ajatellen pääpaino onkin ollut juuri tällaisilla ohjauskäynneillä. On tutustuttu paikallisiin aikuiskoulutuspalveluihin, on yhdessä pohdiskeltu koettuja ongelmia. Näin toisaalta informaatio on kulkenut kuntatasolta lääniin ja toisaalta kuntien työryhmät ovat saaneet työhönsä virikkeitä. Ilman näitä käyntejä lääninhallituksessa on pelkkien kirjallisten raporttien pohjalta hyvin vaikea saada kuvaa käytännössä kohdatuista ongelmista. Kuntien työryhmät ovat laatineet työstään kirjallisia raportteja, joita on toimitettu lääninhallituksen käyttöön. Työryhmien työtä on käytetty hyväksi myös kuntasuunnitelmia laadittaessa. Jossain määrin on tehty tiedotteita aikuiskoulutuspalveluista kuntalaisille.

\section{Panokset}

\section{Osallistujat}

Aikuiskoulutuspalveluja käytetään tyypillisessä kuvitteellisessa Mikkelin läänin kunnassa seuraavaan tapaan:

palvelumuoto

kirjasto

kansalaisopisto

kansanopisto

ammatillinen

aikuiskoulutus

Luvut ilmaisevat vain suuruusluokkia. Ammatillisessa aikuiskoulutuksessa on mukana vain yhteiskunnan tarjoamat palvelut, ei työnantajien järjestämä sisäinen koulutus, joka on ilmeisen suurta.

Opiskelu on harrastusluontoista, vain vähäi'sessä määrin päätoimista. Ammatillinen aikuiskoulutus on tavallaan näistä palvelumuodoista koostuvan järjestelmän kärki. Sen tavoitteena on muuttaa työelämää, sitä jälkeä jonka ihminen työllään maailmaan jättää.

\section{Koulutustarpeet}

Luonteeltaan hallinnollisena kehittämistyönä projektilla ei ole suoranaisia koulutuksellisia tavoitteita. Tavoitteena on koulutuspalvelujen kehittäminen.

\section{Henkilöstö}

Lääninhallituksen työryhmästä on jo edellä kerrottu. Eräissä kunnissa on jossain vaiheessa palkattu päätoiminen sihteeri aikuiskoulutụssuunnitelmaa kunnassa kokoamaan. Kun- tien työryhmissä on ollut varsin usein mukana kansalaisopiston rehtori, elinkeinoasiamies, koulutoimenjohtaja, suunnittelusihteeri ja kunnanjohtaja.

\section{Talous}

Enimmäkseen projektia on vedetty kaikilta osiltaan virkatyönä. Karkeasti arvioiden projektiin on käytetty vuosittain lääninhallituksen ja kuntien virkamiesten työaikaa yhteensä noin 1500 tuntia. Muut kuin työvoimakustannukset ovat olleet erittäin vähäiset.

\section{E. Projektin kehitys}

Projekti on alkanut 1970-luvulla vähitellen lääninhallituksen muun virkatyön ohessa ja se jatkuu yhä. Tässä vaiheessa voidaan hahmottaa kolme kehitysvaihetta:

\section{Keskusjohtoisen suunnittelun vaihe}

Perehdyttiin valtakunnallisiin suunnitelmiin. Kartoitettiin läänin aikuiskoulutuspalvelut ja pyrittiin hahmottamaan kokonaisuudesta käsin laitosten yhteistyötä ja työnjakoa.

\section{Kuntien palveluvarustuksen kartoitusvaihe}

Siirrettiin aikuiskoulutussuunnittelun painopiste kuntiin. Kuntien työryhmät kartoittivat alueensa aikuiskoulutuspalvelut. Palvelujen kehittäminen otettiin mukaan yleiseen kuntasuunnitteluun.

3. Koulutus- ja sivistystarpeiden ja tietohuoltojärjestelmän yhteensovittamisen vaihe

Heräsi kiinnostus selvittää tutkimuksellisin keinoin väestön koulutustarpeet sekä teoreettisesti hahmottaa tietohuoltoon tarvittava kokonaisjärjestelmä: Muodollisesti järjestetyt koulutustilaisuudet ovat vain yksi, joskin tärkeä, osa sitä kokonaisjärjestelmää jolla turvataan läänin tietohuolto.

Mikkelin työssäkäyntialueella on käynnistymässä osaprojekti, aikuiskoulutuskokeilu. Sen ensimäisessä vaiheessa kartoitetaan mahdollisimman huolellisesti alueen väestön koulutustarpeet. Toisessa vaiheessa, osin jo yhtä aikaa ensimmäisen vaiheen kanssa, kehitetään koulutus- ja sivistyspalveluja tuottavien laitosten yhteistyötä. Tavoitteena mm se, että opiskelija voi koota tutkintokokonaisuuksia eri oppilaitoksissa suorittamastaan opiskelusta. Toivottavasti myös valtakunnallisella tasolla tapahtuu tässä asiassa edistymistä.

\section{F. Vaikutukset}

Projektin vaikutuksesta kunnissa on ruvettu kiinnittämään entistä enemmän huomiota aikuiskoulutukseen. Aikuiskoulutus on tärkeä 
osa tietohuoltoa. Tietohuollon kokonaisjärjestelmä on saatava siten toimimaan, että kunnissa ja koko läänissä osaaminen ja taitotieto vahvistuvat. Laajasti ymmärrettynä tietohuolto sisältää myös arkisen kokemustiedon ja elämystiedon välittämisen tieteellistyyppisen tiedon lisäksi.

Aikuiskoulutuspalvelujen kehittämisen suurin este on, ettei riittävästi ymmäretä koulutusja sivistyspalvelujen, siis tietohuollon, merki- tystä kuntien elinkelpoisuuden takaajana, hyvinvoinnin ja viihtyisyyden tekijänä, persoonallisuuden kehittäjänä. Odotetaan helposti vain nopeita taloudellisesti välittömästi mitattavissa olevia tuloksia. Halutaan esimerkiksi tukea elinkeinoelämää suoralla tuella. kuitenkin vain koulutuksella ja sivistystyöllä saavutetaan kestäviä tuloksia. Projektilla pyritään vaikuttamaan siihen, että tietohuollon merkitys kunnissa ja läänissä ymmärretään. Kannattaa investoida osaamiseen ja henkiseen vireyteen. 